ఠ

RETRACTION

\title{
Effect of low-energy extracorporeal shock wave on vascular regeneration after spinal cord injury and the recovery of motor function [Retraction]
}

Wang L, Jiang Y, Jiang Z, Han L. Effect of low-energy extracorporeal shock wave on vascular regeneration after spinal cord injury and the recovery of motor function. Neuropsychiatr Dis Treat. 2016 Aug 31;12:2189-2198. doi: 10.2147/NDT.S82864.

This article was found to have plagiarized the content of:

Low-energy extracorporeal shock wave therapy promotes vascular endothelial growth factor expression and improves locomotor recovery after spinal cord injury published in the Journal of Neurosurgery in 2014 ( $J$ Neurosurg. 121: 1514-1525, 2014).

Accordingly, Dr Pinder, Editor-in-Chief of Neuropsychiatric Disease and Treatment has decided to issue a Retraction notice and advise the academic supervisors of Dr Wang et al of this matter.

Neuropsychiatric Disease and Treatment

\section{Publish your work in this journal}

Neuropsychiatric Disease and Treatment is an international, peerreviewed journal of clinical therapeutics and pharmacology focusing on concise rapid reporting of clinical or pre-clinical studies on a range of neuropsychiatric and neurological disorders. This journal is indexed on PubMed Central, the 'PsycINFO' database and CAS, and is the official journal of The International Neuropsychiatric Association (INA). The manuscript management system is completely online and includes a very quick and fair peer-review system, which is all easy to use. Visit http://www.dovepress.com/testimonials.php to read real quotes from published authors. 